\title{
IMPLIKASI LITERASI MEDIA DALAM MENGUBAH PERILAKU MASYARAKAT KOTA PONTIANAK TERHADAP KABAR BOHONG
}

\author{
Netty Herawati ${ }^{1}$, Aliyah Nur'aini Hanum² ${ }^{2}$ Dewi Utami ${ }^{3}$ \\ ${ }^{1,2,3}$ Prodi Ilmu Komunikasi, Universitas Tanjungpura \\ e-mail: ${ }^{1}$ nettynj@ gmail.com,
}

\begin{abstract}
Whether consciously or not, social media users are active spreaders of fakelfalse news. Those who have an understanding of media literacy should be able to overcome the spread of fakelfalse news. This study intended to examine how media literacy values acquired beforehand by individuals can compete with stimulus in the form of potentially fakelfalse news before it is finally decided to be disseminated or not. This research rests on the principles of social judgment theory and uses in-depth interviews to collect data. The result shows that there is an attitude of restraint when the characteristics of fakelfalse news on a message are successfully marked. In addition, the mismatch of value references possessed by individuals with ideas offered by fakelfalse news lead to 3 types of behavior: muting, compromising, or actively rejecting.
\end{abstract}

Keywords: media literation, hoax, false news, fake news, social judgment

\section{PENDAHULUAN}

Media massa kerap dituding menjadi sumber penyebaran kabar bohong. Hal ini memang sering terjadi terutama di jenis media daring, ketika pihak media melalaikan akurasi hanya karena mengejar kecepatan publikasi berita atau menciptakan judul sensasional demi menarik pengunjung padahal isi berita sama sekali berbeda. Kenyataannya saluran interpersonal adalah saluran utama penyebaran kabar bohong, terbukti dengan hasil survei Mastel (2017) yang menyebutkan media sosial dan aplikasi percakapan sebagai sarana utama penyebaran berita bohong. Pengguna aplikasi percakapan WhatsApp di Indonesia berdasarkan data dari We Are Social sudah mencapai $40 \%$ dari pemilik akses Internet. Melalui WhatsApp, orang dengan mudah mendapatkan kabar dari lingkaran terdekatnya (We Are Social, 2018).
Apalagi, menurut Pablo Ortellado, peneliti berita palsu dan profesor kebijakan publik di Universitas Sao Paulo, orang lebih cenderung mempercayai rumor dari keluarga dan teman. Tidak ada algoritme yang memediasi pengalaman. Ketika informasi yang salah itu datang dalam bentuk teks dan video yang diteruskan - yang terlihat sama dengan pesan pribadi di WhatsApp — mereka memberikan lapisan legitimasi lain. Kemudian Anda mendapatkan efek peracikan jaringan (network compounding effect); jika Anda berada dalam banyak obrolan grup yang semuanya menerima berita palsu, pengulangan membuat mereka lebih dapat dipercaya (Molteni,2018).

Aplikasi percakapan merupakan sarana komunikasi bermedia bagi proses komunikasi interpersonal. Pengaruh emosi dan kedekatan personal yang dimunculkan melalui aplikasi percakapan membuat kabar bohong mudah 
tersebar luas, namun masih menyisakan pertanyaan lain berkaitan dengan pengetahuan literasi media pengguna. Apakah pengetahuan tersebut dapat mencegah atau setidaknya menghambat seseorang untuk menyebarluaskan sebuah kabar yang belum jelas kebenarannya?

Mastel, atau Masyarakat Telematika, sebuah wadah bagi pemangku kepentingan di bidang Telekomunikasi, Teknologi Informasi, Komunikasi dan Penyiaran, melaksanakan sebuah survei daring mengenai wabah hoaks pada tanggal 7 Februari 2017. Salah satu hasil temuan yang didapatkan adalah mengenai frekuensi menerima hoaks. Sebanyak 44,30\% responden mengakui menerima hoaks setiap hari, dan sebanyak $84,5 \%$ merasa terganggu dengan adanya berita hoaks. Untuk menanggulangi problem ini, sejumlah $57,7 \%$ responden menyebut cara terbaik adalah melalui edukasi masyarakat. Upaya memberikan edukasi kepada masyarakat terkait dengan isi media ini kerap disebut dengan istilah literasi media.

Banyak pihak sepakat bahwa literasi media adalah jawaban dari masalah kabar bohong. Tingginya pendidikan formal tidak menjamin seseorang mampu mengontrol dirinya untuk menyebarkan sebuah kabar yang belum diketahui kebenarannya. Kesepakatan ini dapat dilihat dari terbentuknya forum-forum di dalam masyarakat dan lembaga-lembaga resmi pemerintah yang mendeklarasikan perang terhadap kabar bohong. Beberapa grup yang lahir karena gerah dengan maraknya kabar bohong, antara lain Forum Anti Fitnah, Hasut, dan Hoax (FAFHH), Fanpage \& Group Indonesian Hoax Buster, Fanpage Indonesian Hoaxes, dan Grup Sekoci. Empat grup ini semuanya terdapat di Facebook (Yusuf, 2017).

Di antaranya yang terbesar adalah MAFINDO, Masyarakat Anti Hoax Indonesia. MAFINDO adalah organisasi perkumpulan resmi yang didirikan pada tanggal 19 November 2016, beranggotakan para relawan yang mengelola situs TurnBackHoax.ID dengan mengambil sumber konten dari Forum FAFHH, Forum Anti Fitnah Hasut dan Hoax yang beralamat di http://facebook.com/groups/fafhh.

Melalui situs tersebut, selain menampilkan arsip mengenai kabar bohong, MAFINDO juga memberikan akses bagi masyarakat untuk melakukan pelaporan mengenai suatu kabar yang diindikasikan bohong, untuk ditelusuri lebih lanjut dan diketahui apakah benar, salah, atau hanya perlu diluruskan saja.

Di kota Pontianak dalam kurun waktu 20172018 sudah dilakukan sedikitnya 10 kali kegiatan yang bertujuan untuk melawan kabar bohong, belum termasuk kegiatan-kegiatan internal lembaga yang tidak dipublikasikan di media massa lokal. Kegiatan-kegiatan tersebut masih di luar pidato, ceramah, maupun sambutan yang banyak disampaikan oleh pejabat-pejabat pemerintah yang mengingatkan 
bahaya berita bohong. Tak kurang banyaknya diskusi kelas yang dilakukan para pendidik dan pengajar di sekolah-sekolah dan universitas.

Belakangan, kegiatan ini marak diadakan di kota Pontianak dan sekitarnya terutama menyusul jatuhnya korban jiwa akibat kabar bohong mengenai korban yang tewas dihakimi massa gara-gara dituduh sebagai pelaku jual beli organ tubuh anak-anak (Sinaga, 2017).

Tidak ada yang bisa memastikan apakah jatuhnya korban jiwa memang menjadi semacam terapi kejut bagi masyarakat untuk lebih berhati-hati dalam menyikapi sebuah kabar atau kesadaran intelektualitas individual yang timbul berkat kegiatan-kegiatan literasi media yang giat memberantas kabar bohong. Kabar bohong terus muncul setiap hari langsung masuk tanpa permisi ke perangkat yang sehari-hari kita pegang, telepon seluler.

Penelitian ini menggunakan Social Judgment Theory (Teori Penilaian Sosial) dari Muzafer Sherif sebagai landasan untuk analisis. Teori ini memberikan perhatian pada bagaimana orang menilai segala informasi atau pernyataan yang didapatkannya. Tepatnya, berupaya memperkirakan bagaimana orang menilai pesan dan bagaimana penilaian yang dibuat tersebut dapat memengaruhi sistem kepercayaan yang sudah dimiliki sebelumnya.

Menurut teori penilaian sosial, ada 4 hal yang menentukan seseorang akan menerima, menolak, atau bersikap netral terhadap suatu pesan, yakni apakah pesan tersebut berada di latitude of acceptance, latitude of rejection, latitude of noncommitment, dan seberapa besar keterlibatan ego orang tersebut di dalamnya.

Dengan demikian, peneliti berharap dapat mengetahui, apakah dan bagaimana kabar bohong dapat memengaruhi orang-orang yang sudah memiliki pengetahuan mengenai literasi media untuk mempercayai dan menyebarkan kabar bohong tersebut.

\section{METODOLOGI PENELITIAN}

Penelitian ini menggunakan metode penelitian kualitatif karena pada penelitian ini peneliti tidak bermaksud untuk mengukur secara angka-angka dan statistik sebuah fenomena, melainkan untuk memahami karakter dari fenomena tersebut. Terdapat 2 kategori informan yang terbagi atas mereka yang mengikuti pelatihan mengenai literasi media/anti hoaks dan mereka yang mempelajari hal ini secara otodidak.

Peneliti melakukan wawancara mendalam dengan 10 orang warga kota Pontianak untuk mendapatkan pemahaman mereka mengenai literasi media dan kabar bohong, juga mendengar pengalaman mereka saat berhadapan dengan kabar bohong.

\section{HASIL DAN PEMBAHASAN}

Maraknya kasus berita bohong diiringi gencarnya istilah hoaks menghiasi aneka pemberitaan oleh media, membuat khalayak mau tidak mau penasaran untuk mencari tahu 
apa maksud hoaks. Bahkan Kamus Besar Bahasa Indonesia segera menyerap istilah asing hoax menjadi hoaks sehingga membuatnya semakin akrab di telinga masyarakat. Secara umum, para informan dapat memahami unsur utama dari sebuah hoaks, yakni adanya kebohongan yang dibuat dengan sengaja. Seperti yang diungkapkan oleh salah seorang informan, Dini, yang memaknai hoaks sebagai berita palsu yang dikemas seolah-olah benar. Demikian pula Destiandi yang menyebutnya kabar yang tidak bisa dipertanggungjawabkan atau tidak sesuai fakta. Senada pula dengan jawaban dari Mutadi, yang mengatikannya sebagai sebuah informasi tentang sesuatu yang tidak benar-benar terjadi atau sesuatu yang terjadi tetapi tidak faktual atau bertolak belakang dengan fakta sesungguhnya.

Seperti yang telah diungkapkan oleh penelitian-penelitian terdahulu, media sosial adalah kendaraan utama penyebar luas kabar bohong. Itu pula yang diyakini oleh Asep. Ia menyebut hoaks sebagai berita dan atau informasi yang dibuat atau sengaja dibuat dan disebarkan kepada umum, biasanya melalui media sosial. Tentu saja berita atau informasi ini yang belum jelas kebenarannya atau belum terbukti keakuratannya. Asep secara objektif merujuk kepada dua kemungkinan, ketika informasi tersebut dibuat atas ketidaktahuan atas ketidakakuratan peristiwa, dan ketika memang dibuat atas dasar kesengajaan. Hal ini berbeda dengan Habib yang meyakini bahwa kabar bohong adalah semata-mata sebuah usaha untuk menipu atau mempercayai sesuatu kebenaran dengan kepalsuan. Pernyataan ini memiliki kemiripan dengan pemahaman dari Cindy, hoaks dipandang sebagai berita yang tidak sesuai dengan realita, atau dengan kata lain sengaja dimanipulasi demi kepentingan tertentu.

Lebih jauh lagi, informan berikutnya, Atiqa, menyoroti soal kerugian yang kelak ditimbulkan berkat penyebaran kabar bohong tersebut. Atiqa juga memilih menyebut hoaks sebagai "informasi" ketimbang "berita", yakni informasi yang disebarkan kepada khalayak ramai dengan tidak menggambarkan keadaan yang sebenarnya. Dengan kata lain, tidak berisi fakta sehingga tidak dapat dipertanggungjawabkan kebenaran isi informasinya dengan maksud tertentu yang dapat dapat merugikan pihak tertentu. Bukan sekedar kerugian secara umum. Informan lainnya, Dwi, menekankan potensi timbulnya konflik di masyarakat serta aksi-aksi radikalisme. Kabar bohong sendiri menurut Dwi, bisa berupa berita, ujaran, atau pemahaman tentang bagaimana berita itu seolah-olah benar.

Pernyataan Asep menunjukkan adanya pemahaman lebih yang ia miliki dibandingkan informan lainnya. Mengingat dalam kenyataannya tidak semua kabar bohong atau hoaks yang beredar di masyarakat dibangun atas keinginan untuk melakukan penipuan atau 
manipulasi, melainkan bisa terjadi karena misinformasi dan disinformasi. Dalam modulnya yang berjudul Combatting disinformation dan misinformation through Media and Information Literacy (Ireton \& Posetti 2018), Magda Abu-Fadil mencontohkan misinformasi dengan kasus penyelamatan seorang gadis di Meksiko yang terperangkap reruntuhan bangunan akibat gempa tahun 2017. Setelah ditelusuri ternyata diketahui gadis itu tidak benar-benar ada, alias fiktif. Misinformasi mengacu pada infomasi keliru atau salah, sementara disinformasi merujuk pada penyebaran informasi salah yang disengaja demi menimbulkan kebingungan dan menyesatkan masyarakat.

Asep membagikan pengalamannya ketika ia merasa dirugikan oleh pihak yang menggunakan foto dirinya. Ada 2 hal yang patut diwaspadai berkaitan kabar yang beredar di masyarakat, yakni disinformasi dan misinformasi, Asep menyampaikan kejadian yang merujuk pada disinformasi. Ketika dirinya yang tidak memiliki sangkut paut dengan lembaga simpan pinjam tersebut ternyata malah fotonya dipergunakan untuk kepentingan promosi. Menurut Asep, jika sampai dianggap menguntungkan tentulah hanya dialami oleh sekelompok orang saja.

Kabar bohong pada umumnya merugikan dan ia tak pernah diuntungkan, malah merasa dirugikan atas beberapa kejadian, salah satunya adalah ketika identitasnya wajahnya dipakai, "yang paling fenomenal adalah penggunaan foto saya oleh salah satu channel BBM tanpa izin." Kondisi ini membuat seolah-oleh dirinyalah yang menangani channel di aplikasi Blackberry Messenger tersebut, mengirim semua informasi, dan merespon terhadap semua percakapan yang terjadi.

Motif ekonomi juga menjadi sorotan Dini terkait keuntungan dari penyebaran kabar bohong,

"mungkin saja [menguntungkan], yaitu bagi para pelaku kejahatan dunia maya yang memanfaatkan hoax sebagai clickbait dalam rangka mendapatkan banyak views untuk web atau video mereka di YouTube."

Lazim di media yang kontennya diunggah oleh para pengguna [user generated content], para pengiklan akan tertarik untuk berpromosi di channel yang dikunjungi dan dan ditonton banyak orang. Semakin sensasional judul video - lepas dari benar atau tidaknya kejadiannya, atau ada keseuaian atau tidak antara judul dan isi video - semakin banyak orang yang penasaran untuk berkunjung dan menonton video tersebut. Dini melanjutkan,

“jika penerima berita percaya berita begitu saja tanpa melakukan cross check akan kebenaran berita, bisa jadi merugikan. Apalagi jika hoax tersebut terkait misalnya, praktik kesehatan yang dapat membahayakan keselamatan masyarakat."

Secara pribadi, ia mengakui belum pernah merasa dirugikan oleh kabar bohong, namun di sisi lain ia juga tidak merasa diuntungkan sama 
sekali oleh kabar bohong. Ia yakin, kabar bohong itu merugikan.

Dorongan untuk mendapatkan keuntungan berupa materi juga menjadi pendapat Habib berkaitan dengan penyebaran kabar bohong, "Karena studi kasus di Indonesia, hoaks memiliki agen yang besar di media sosial dan tentunya memiliki jaminan keuntungan materi atau finansial, seperti kasusnya Saracen News." Habib menilai masyarakat sangat merugikan, karena kabar bohong membungkus kebenaran dengan kepalsuan, membuat masyarakat bahkan dirinya sendiri bingung menentukan mana yang benar dan palsu.

Manfaat kabar bohong diduga juga dirasakan oleh mereka yang bergerak mencari dukungan politik atau justru menjatuhkan lawan politik. Seperti dikemukakan oleh Atiqa,

"mungkin saja [menguntungkan], terutama keuntungan bagi para penyebar hoax itu sendiri karena penyebar informasi memiliki tujuan khusus...tertentu. Mungkin para pendukung salah satu caleg atau capres diuntungkan dengan berbagai penyebaran informasi hoax sehingga menaikkan elektabilitas salah satu calon atau orang tersebut. Jelas [kabar bohong] merugikan karena informasi yang disebarkan tidak bernilai positif justru sebaliknya [negatif]. Informasi yang disebarkan kepada orang lain dengan tidak menggambarkan keadaan yang sebenarnya dapat merugikan pihak lain karena informasi bernilai guna salah satunya sebagai pengambil keputusan seseorang. Jika seseorang salah mengonsumsi informasi maka dapat berakibat salah dalam pengambilan keputusan dan ini jelas merugikan pihak tersebut pada saat itu juga ataupun di kemudian hari."
Sejalan dengan pendapat Atiqa yang menilai adanya kepentingan sepihak, Mutadi mengaku mengetahui ada pihak-pihak yang diuntungkan berkat penyebaran kabar bohong, "misalnya klaim pemerintah atas pembangunan 65 bendungan, 300 lebih ruas jalan tol baru, keuntungannya jelas dinikmati oleh pemerintah yang akan kembali berkuasa." Di sisi lain, kabar bohong juga merugikan karena dapat membentuk opini negatif pada diri sebagian orang lain.

Kerugian lain yang mungkin timbul akibat kabar bohong ini menurut Dwiyogo, "mungkin saja [merugikan] bila berita atau muatan itu dapat menimbulkan konflik sosial." Kemudian ia mempertegas jawabannya dengan mengatakan bahwa kabar bohong sangat merugikan berbagai pihak karena tidak dapat dipertanggungjawabkan dan bertentangan dengan Undang-Undang ITE pasal 27. Pengaturan UU ITE di pasal 27 ini berisi soal perbuatan yang dilarang (cybercrimes).

Sebagian informan dalam penelitian ini tidak pernah secara formal duduk di sebuah ruang kelas untuk mendapatkan pelatihan mengenai apa itu literasi media atau apa itu hoaks. Namun kesemua informan memiliki kesamaan sikap, bahwa kabar bohong perlu diperangi, dan untuk memeranginya perlu amunisi yang cukup. Separuh dari informan mengaku secara aktif mencari tahu sendiri apa dan bagaimana menghadapi dan mengatasi kabar bohong. 
Asep, satu-satunya informan yang pernah mengikuti pelatihan untuk menjadi "Kader Anti Hoax" menyebutkan bahwa literasi media pada prinsipnya adalah pemahaman atau pengetahuan tentang media secara umum. Ia mengaku mendapatkan informasi dan teknikteknik sederhana mengecek hoaks. Tak hanya itu, pemahaman tentang hoaks juga ia teruskan kepada yang lain, karena ia percaya bahwa setiap orang punya tanggung jawab yang sama melawan hoaks.

Pemaparan sedikit berbeda muncul dari Habib yang lebih mengacu kepada kecerdasan dalam menggunakan sebuah produk media, yakni bagaimana seseorang memahami dan menganalisa sebuah produk dari media, sehingga mampu memilah dan memilih mana produk media yang baik dan bisa menjadi referensi dalam berpikir dan bertindak. Setelah mengikuti pelatihan, Habib merasa mendapatkan sebuah pemahaman baru yang mempengaruhi perilakunya,

"setelah mengikuti kegiatan tersebut saya lebih berhati-hati dalam membagikan sebuah kabar berita yang tidak menutup kemungkinan terkandung dan terdapat kabar bohong atau hoaks. Jadi bukan hanya judul yang dibaca lalu dibagikan tanpa memahami dan mengetahui sumber dan referensinya apakah kredibel atau tidak."

Kontrol terhadap sikap menjadi penekanan Meriana,

"cara menghindari menurut saya, jangan pernah cepat bereaksi atau bersikap atas suatu pemberitaan, jangan langsung percaya atas suatu pemberitaan, dan jangan langsung menyebarluaskan pemberitaan tersebut tanpa mengetahui kebenaran berita tersebut."

Berbeda dengan mereka yang mengikuti pelatihan secara khusus, para informan yang secara swadaya memperkaya ilmunya mengenai literasi media ternyata menangkap maknanya secara lebih sempit, yakni literasi media berarti mampu melakukan determinasi antara pemberitaan bohong dan berita yang berbasis fakta. Dikatakan dikatakan Dwiyogo, "dengan literasi media berarti bisa mencari serta menganalisa suatu berita apakah dikatakan nyata atau berpotensi kebohongan dengan mencari literatur-literatur lain. “

Informan lainnya, Atiqa, mengaku juga tidak pernah mengikuti kegiatan seperti itu,

"hanya saja [saya] membaca artikel dan mengikuti suatu diskusi di forum atau grup media sosial di mana beberapa hal yang dapat dilakukan untuk menghindari hoax adalah dengan pengecekan sumber, baik keabsahan sumber yang menyebarkan informasi, kredibilitas sumber, tahun atau waktu penyebaran. Tentu hal tersebut menambah pengetahuan saya agar terhindar dari informasi hoax."

Apa yang ia pelajari, juga diterapkan oleh Atiqa,

"penerapan sehari-hari, misalnya ketika mendapatkan broadcast tentang suatu informasi, sebaiknya analisis atau membaca informasi yang disebarkan dengan cermat, kemudian coba lakukan pengecekan ke beberapa sumber yang membahas topik tersebut. Jika data di dalam informasi yang disebarkan sama dengan beberapa sumber yang diperoleh, maka informasi tersebut 
dapat dipertanggungjawabkan dan layak konsumsi."

Senada dengan apa yang dijabarkan oleh Atiqa, Dini memahami literasi media sebagai kemampuan masyarakat untuk memahami berita yang mereka dapatkan melalui media, serta kecakapan masyarakat dalam menyikapi suatu berita. Dini melanjutkan,

"Sejak membaca lebih detail mengenai hoax dan printilan-nya, saya jadi lebih berhatihati dalam memercayai sebuah berita. Saya juga selalu melakukan verifikasi berita jika ingin ikut menyebar sebuah berita lewat akun media sosial pribadi."

Diungkapkan oleh Mutadi, yang juga sempat menjalani pofesi sebagai jurnalis, memaknai literasi media sebagai kemampuan seseorang untuk melihat, membaca, mendengar, memahami sesuatu informasi melalui media dan menggunakannya secara efektif dan mampu mengomunikasikan informasi tersebut ke dalam berbagai format yang jelas dan mudah dipahami.

Tampak jelas para informan menyadari bahayanya kabar bohong, sehingga baik secara mandiri mencari informasi tentang literasi media atau mengikuti pelatihan, muncul keinginan untuk menjadi pribadi yang lebih bertanggung jawab. Tidak hanya mereka merasa perlu menyaring untuk kepentingan personal, melainkan juga kaitannya dengan penyebarluasan kabar tersebut ke pihak-pihak lain.
Berbagai penelitian menunjukkan bahwa di berbagai belahan dunia orang muda tidak bisa melepaskan hidupnya dari perangkat seluler. Dengan alat ini mereka mendapatkan sebagian besar berita mereka melalui aplikasi obrolan, media sosial, dan, kadang-kadang, situs media tradisional dan blog (Abu-Fadil dalam Ireton \& Posetti, 2018). Oleh karena itu, penting bagi penelitian ini untuk memahami kebiasaan informan dalam mengonsumsi berita setiap harinya.

Walaupun kerap mendapatkan berita dari group chat Whatsapp dan akun-akun di Instagram, tirto.id adalah portal berita favorit dan dianggap terpercaya oleh Habib. Menurutnya, artikel-artikel yang ia jumpai di tirto.id ditulis berdasarkan analisis, "Referensi [sumber] berita yang mereka gunakan sangat kredibel, [menyajikan] fakta, dan independen."

Senada dengan Habib, Dini juga mendapatkan variasi berita harian dari ragam sumber daring, seperti Facebook, Instagram, Twitter, detik forum, dan beberapa portal berita yang muncul di beranda saat membuka halaman Google di browser Chrome pada smartphone. Dini menaruh kepercayaannya pada portal berita, “...karena portal yang saya akses merupakan portal yang insyaallah valid dan terpercaya."

Mengunjungi satu portal berita ke portal berita lainnya bisa menjadi pekerjaan melelahkan bagi sebagian orang. Apalagi portal berita kerap dipenuhi oleh iklan yang 
mengganggu kenyamanan membaca. Jalan keluar yang bisa diambil adalah dengan menggunakan aplikasi yang secara otomatis melakukan kompilasi atas berita-berita terakhir dari berbagai sumber, yang disebut juga aggregrator. Saat ini salah satu aggregrator yang populer di Indonesia adalah Line Today, yang terintegrasi dengan aplikasi percakapan Line. Atiqa menyukai Line Today karena bisa mendapatkan ragam berita dari yang ringan sampai yang hangat dengan mudah. Ia juga sering mendapatkan ragam berita dari akunakun yang ia ikuti di media sosial Twitter, Facebook, dan Instagram. Walaupun usianya tergolong generasi $\mathrm{Z}$ yang umumnya terpikat pada media Internet, ternyata Atiqa menganggap yang paling dapat dipercaya adalah televisi,

“...karena dengan televisi, bisa membandingkan beberapa berita yang memiliki kesamaan topik melalui berbagai varian channel televisi. Apalagi yang beritanya sedang menjadi trending atau headline maka hampir semua saluran televisi akan membahasnya dari situ bisa membandingkan antara berita di channel satu dengan lainnya."

Media massa kerap dituding menjadi sumber penyebaran kabar bohong. Hal ini memang sering terjadi terutama di jenis media daring, ketika pihak media melalaikan akurasi hanya karena mengejar kecepatan publikasi berita atau menciptakan judul sensasional demi menarik pengunjung padahal isi berita sama sekali berbeda. Kenyataannya saluran interpersonal adalah saluran utama penyebaran kabar bohong, terbukti dengan hasil survei Mastel (2017) yang menyebutkan media sosial dan aplikasi percakapan (chatting) saluran penting penyebaran berita bohong yakni sebanyak $62,80 \%$, menyusul di belakang media sosial yang sebagai sarana utama yakni sebesar $92,40 \%$. Bagaimana dengan para informan penelitian ini?

Asep mengaku hari-harinya nyaris tak pernah sepi dari kabar bohong yang mampir melalui aplikasi pesan singkat atau WhatsAppnya. Ia meyakini pesan-pesan tersebut adalah kabar bohong karena kerap disertai ajakanajaan untuk menyebarkan, "pada umumnya [di dalam pesan] ada ciri [kata-kata] 'sebarkan' atau 'viralkan'... saya tidak pernah menanggapi." Apabila ada informasi yang dianggap meresahkan, Asep kerap menggunakan alat bantu perangkat lunak untuk mengecek kebenarannya seperti hoax checker, dan banyak perangkat lainnya.

Dari banyak berita yang ia terima, Mutadi menandai berita bohong yang minim atau bahkan tidak memiliki data jelas mengenai institusi medianya, “...bukan media resmi sebagaimana diatur dalam UU tentang Pers dan narasumbernya tidak kredibel dan tidak memiliki kapabilitas." Dari cara berita itu disajikan juga cenderung memiliki ciri-ciri tertentu, seperti judul yang bombastis, bermuatan SARA, provokatif, dan memunculkan nada (tone) negatif. 
Dalam ruang lingkup pergaulan, seseorang seringkali harus mengakomodir keinginan berbagai pihak untuk memasukkan dirinya ke dalam grup percakapan di telepon seluler. Semakin luas pergaulannya, semakin banyak bergabung di dalam grup percakapan, yang notabene akan semakin banyak juga pesan yang masuk mengalir memenuhi telepon seluler.

Atiqa adalah salah satu contoh penerima berita bohong melalui grup percakapan di WhatsApp. Menurutnya, kabar yang tidak mencantumkan informasi sumber yang jelas dan kredibel di akhir pesan sudah menunjukkan ciri awal bahwa informasi tersebut adalah hoaks. Selesai membaca informasi biasanya Atiqa juga langsung menganalisisnya untuk mengetahui kebenaran berita tersebut dengan mengecek kredibilitas sumber yang tercantum pada informasi yang disebarkan.

Analisis isi pesan juga dilakukan oleh Habib, “...dengan analisis dan bukan hanya membaca setengah-setengah." Membaca berita tak sampai selesai bahkan sekedar membaca judulnya saja adalah kebiasaan buruk banyak orang yang tidak memahami bahayanya kabar bohong. Ketika judul sebuah berita atau foto menggugah emosi, berpotensi untuk disebarkan oleh banyak orang dalam waktu singkat. Lebih jauh lagi, Habib mengecek akurasi berita menggunakan layanan yang disediakan di hoaxornot.detik.com

Di luar segala aksi proaktif yang bisa dijalankan untuk mengetahui apakah suatu kabar itu benar atau tidak, sebenarnya seseorang bisa melakukannya secara pasif dengan menunggu perkembangan berita. Menurut Dini, biasanya, kabar bohong yang tersebar akan mendapatkan bantahan selang waktu beberapa hari kemudian bahkan dalam beberapa jam saja. Hanya dengan memantau laman Facebook yang berisi kabar tersebut, segala jenis komentar akan muncul, termasuk yang memberikan klarifikasi maupun bantahan.

Sebaik apapun seseorang memilih sumber informasi yang paling dipercaya, tetap saja tidak mungkin bisa menghindari datangnya kabar bohong, seperti paparan Atiqa,

"karena informasi saat ini sangat mudah untuk diciptakan kapan saja, dimana saja, oleh siapa saja, dan menggunakan media apa saja, tanpa melalui proses editing dari ahlinya, sehingga ini berpotensi banyaknya informasi yang tidak bernilai guna positif dikonsumsi oleh masyarakat awam yang belum melek terhadap informasi dan media yang dapat mengakibatkan kesalahan dalam pengambilan keputusan mereka. Perlu diketahui bersama bahwa informasi yang beredar tiap detiknya saat ini justru banyak memberikan informasi ringan yang hanya berisi propaganda, tidak mendidik, persuasif, dan doktrin. Sehingga sangat perlu untuk setiap orang melek terhadap media dan informasi."

Risiko tinggi yang ditimbulkan penyebaran kabar bohong menyebabkan semua informan sepakat bahwa pengecekan akurasi berita amatlah penting. Asep bahkan memandangnya sebagai tanggung jawab moral setiap individu. Habib menilai aktivitas meneruskan berita bohong sama saja dengan bertindak pelaku 
utama yang memunculkan kabar itu pertama kali, “...maka harus lebih bijak dan hati-hati, karena jempolmu harimaumu." Ditambahkan pula oleh Dini soal mempertajam kemampuan mental, "[pengecekan akurasi berita] itu perlu, agar tidak tersesat dengan informasi yang keliru dan membentuk pola pikir kritis."

Sepandai-pandainya menghindari peran sebagai penyebar kabar bohong, terkadang kecerobohan juga terjadi. Beberapa informan mengakui keteledoran mereka saat ikut menyebarkan sebuah kabar yang ternyata tidak benar melalui media sosial, seperti pengalaman Atiqa,

“...pernah [menyebarkan kabar bohong], ketika orang yang menyebarkan berita tersebut adalah orang yang punya posisi seperti pimpinan, keluarga, atau teman dekat, sehingga ada kepercayaan...ketidakraguan saya untuk menyebarkan informasi tersebut kepada orang lain."

Teori Penilaian Sosial yang dikembangkan oleh Muzafer Sherif menyatakan bahwa perubahan sikap seseorang terhadap objek sosial dan isu tertentu merupakan hasil proses penilaian yang terjadi dalam diri orang tersebut terhadap pokok persoalan yang dihadapi. Proses "menilai" isu atau objek sosial tersebut menurut Sherif berpatokan pada kerangka rujukan yang dimiliki seseorang. Kerangka rujukan inilah yang pada gilirannya menjadi "jangkar" untuk menentukan bagaimana seseorang memposisikan suatu pesan persuasif yang diterimanya. Lebih jauh
Sherif menegaskan bahwa tindakan memposisikan dan menyortir pesan yang dilakukan oleh alam bawah sadar kita terjadi sesaat setelah proses persepsi. Di sini kita menilai setiap gagasan baru yang menerpa kita dengan cara membandingkannya dengan sudut pandang kita saat itu.

Dengan kata lain teori ini menyatakan bahwa perubahan sikap seseorang terhadap objek sosial atau isu tertentu merupakan hasil proses penilaian yang terjadi dalam diri orang tersebut terhadap pokok persoalan yang dihadapi. Proses menilai isu atau objek sosial tersebut berpatokan pada kerangka rujukan yang dimiliki seseorang. Kerangka inilah yang menjadi rujukan bagaimana seseorang memposisikan dan menyortir pesan yang diterima dan membandingkannya dengan sudut pandang yang rasional. Dalam konteks implikasi literasi media, penelitian ini bermaksud untuk mencari tahu, apakah persuasi yang disampaikan oleh sumber atau penyebar kabar bohong dapat membujuk masyarakat untuk mempercayai kabar tersebut sekaligus menyebarluaskannya ketika informan telah mengenali dan memahami misinformasi dan disinformasi.

Di era berbagi informasi saat ini, konten yang viral menjadi cita-cita semua pembuat konten, tak cuma pembuat materi promosi, melainkan juga pembuat konten hoaks. Viralnya pesan menjadi subjek penelitian yang menarik, termasuk yang dilakukan oleh Berger 
\& Milkman (2012) yang berupaya mencari jawaban dari pertanyaan mengapa potongan konten daring tertentu — misalnya iklan, video, atau artikel berita - bisa lebih viral daripada yang lain. Dalam artikelnya yang berjudul “What Makes Online Content Viral?” mereka menjelaskan pendekatan psikologis yang dipergunakan untuk memahami difusi. Menggunakan kumpulan data unik dari semua artikel New York Times yang diterbitkan selama periode tiga bulan, para penulis menyelidiki bagaimana emosi membentuk viralitas. Hasilnya menunjukkan bahwa konten positif lebih viral daripada konten negatif. Viralitas sebagian didorong oleh gairah fisiologis. Konten yang membangkitkan emosi positif tinggi (kagum) atau negatif tinggi (marah atau kecemasan) lebih bersifat viral. Konten yang membangkitkan rangsangan rendah, atau menonaktifkan emosi (misalnya, kesedihan) kurang viral.

Konten yang membangkitkan emosi tinggi adalah hal yang jamak dijumpai dari kabarkabar bohong yang tersebar di berbagai media. Emosi positif kerap diasosiasikan dengan kegembiraan yang bersumber dari sesuatu yang disukai dan diminati. Masing-masing individu memiliki minat dan kebutuhan pada bidang tertentu, sehingga konsumsinya terhadap informasi pun mengacu kepada dua hal tersebut. Dengan kemudahan untuk berbagi melalui perangkat seluler, hal-hal yang menjadi perhatian seorang individu pun berpotensi untuk disebarluaskan. Dengan kata lain, diindikasikan bahwa kabar bohong yang muncul dalam topik yang disukai informan akan menjadi stimulus yang sulit ditolak oleh mereka.

Peneliti telah menanyakan kepada para informan mengenai topik-topik apa yang kerap menarik perhatian mereka. Hasilnya menunjukkan bahwa stimulus semacam ini ternyata tidak berada di area garis lintang penerimaan, melainkan berada di dalam garis lintang ketidakterlibatan.

Di antaranya, Cindy. Ia mengaku sangat menyukai segala sesuatu yang terlihat lucu dan unik dalam bentuk gambar. Sesekali ia juga membagikan lelucon dalam bentuk gambar. Lelucon atau humor memiliki titik kritis karena memiliki banyak ragam. Salah satu jenisnya adalah parodi atau satir yang kerap mengelabui apabila orang menangkap maknanya secara harfiah. Padahal parodi membutuhkan telaah yang lebih mendalam untuk bisa mengerti arti pesan yang hendak disampaikan. Ternyata Cindy juga memahami titik kritis ini, "biasanya saya lebih tertarik untuk membagikan sesuatu yang bersifat hiburan. Termasuk juga humor, tetapi juga dipertimbangkan [terlebih dahulu]. Konteks gurauan tidak [boleh] menyinggung siapapun, yang sifatnya umum." Dari pernyataan ini terbaca bahwa Cindy tidak memiliki komitmen apapun terhadap apa yang ia sukai. Apa yang ia sukai tak lantas harus dibagikan. Jikalau harus dibagikan pun, Cindy 
ingin memastikan bahwa semuanya akan amanaman saja.

Emosi negatif biasanya dihubungkan dengan kemarahan dan kecemasan, emosi yang lazim menjadi "barang dagangan" para penyebar kabar bohong yang bertemakan politik, agama, atau suku. Salah satu informan, Mutadi, menyebutkan bahwa politik adalah salah satu tema favoritnya untuk berbagi,

"[saya] ingin berbagi apa yang dapat menjadi informasi positif kepada pembaca atau pengguna media sosial lainnya. Sejak akhir tahun 1998 saya menjadi jurnalis di sebuah media cetak hingga memiliki media online sendiri pada tahun 2010, meski tahun 2013 terpaksa dipindahtangankan pengelolaannya kepada pihak lain karena tidak adanya sumber daya manusia untuk menanganinya. Dari pengalaman itu saya selalu suka dengan informasi-informasi yang bersifat positif untuk dibagikan kepada pembaca lainnya."

Mutadi juga sering memilih artikel dengan bahasan yang detail agar pembaca langsung memiliki pemahaman tentang sebuah informasi yang dibaca. Dengan kepeduliannya untuk berbagi, tidak lantas Mutadi melupakan selektivitas dalam memilih media, “... bisa dipercayai. Alasannya, sumber informasi yang dibagikan berasal dari media massa online yang memenuhi persyaratan undang-undang sebagai media." Mutadi tidak terbujuk untuk meneruskan rantai kabar bohong politik.

Sama halnya dengan Habib. Sajian berita mengenai politik adalah yang utama ia pilih untuk dibagikan, dimotivasi oleh keinginan untuk memberikan pemahaman politik sekaligus membantu menyebarkan mana berita yang benar dan berita yang palsu. Untuk memastikan keakuratan fakta, Habib berupaya mencari referensi artikel berita yang mendetail. Dipaparkannya,

"karena [saya] memiliki background keilmuan berkaitan dengan bidang ilmu politik [dan saya juga mendapatkan fakta] yang berdasarkan hasil survey [oleh] Masyarakat Telematika Indonesia pada tahun 2017 [yang menyebutkan bahwa] dari 1000 reponden merilis data bahwa $91.8 \%$ masyarakat Indonesia menerima kabar hoax perpolitikan dan isu SARA dari aplikasi media sosial. Maka saya tertarik turut membantu menyebarkan sebuah berita yang sudah terbukti keasliannya sesuai fakta yang ada."

Bahasan mengenai agama sering menjadi perdebatan panas di media, emosi tinggi kerap terpancing melalui diskusi ini. Bagi Dini, berbagi ilmu agama adalah hal yang penting,

“...misalnya tentang pentingnya melunasi hutang dan menjauhi riba. Karena informasi tersebut bermanfaat untuk saya secara pribadi, dan saya merasa teman-teman saya pun dapat merasakan manfaat dari informasi yang saya bagikan. Kadang saya membagikan informasi singkat dan umum saja. Misalnya, tentang hadits mengenai gempa bumi. Atau artikel tentang pembahasan hadits mengenai orang munafik. Sewaktu-waktu saya pun membagikan informasi yang mendetail, dengan harapan, seperti yang saya sebutkan, teman-teman saya ikut mendapatkan manfaat dari informasi yang saya dapat, meskipun mungkin memiliki pemahaman dan persepsi berbeda mengenai berita yang saya bagikan." 
Bagi Dini stimulus yang diberikan kabar bohong dengan bungkus agama adalah hal yang berbeda. Ia berupaya mencari referensi sebanyak-banyaknya untuk memastikan bahwa ilmu mengenai agama yang ia sampaikan tidak salah karena memang tak boleh salah, “...hal yang bersifat prinsip seperti agama yang memang sudah ada pedoman dari sananya."

Dari pemaparan di atas, ditemukan pola menarik dari garis lintang ini. Semula diduga bahwa konten yang cenderung mengundang emosi tinggi dapat membujuk para informan peminat isu panas sehingga membuat mereka berada di wilayah garis lintang penerimaan. Namun ternyata, pemahaman informan berkenaan dengan misinformasi dan disinformasi dari literasi media membuat mereka mampu melepaskan komitmen dengan cara memfilter isi pesan dan hanya membagikan kabar yang nyata positif untuk masyarakat.

Penelitian ini juga menemukan efek asimilasi yang ditimbulkan oleh isu yang seharusnya muncul di dalam wilayah garis lintang penolakan malah hadir di dalam wilayah garis lintang penerimaan. Sebagian informan secara tegas mampu menandai kabar bohong, menolak untuk menyebarkannya, namun merasa berat untuk menentang ide itu secara terbuka sehingga terkesan menerima atau seolah-olah memberikan kompromi terhadap ide yang keliru tersebut.
Diceritakan oleh Ganis, niat baiknya untuk meluruskan kabar bohong dalam grup percakapan keluarga di WhatsApp ternyata tidak mendapatkan respon sama sekali dari anggota grup lainnya. Ini merupakan suatu kondisi yang menunjukkan fenomena posttruth. Dijelaskan dalam artikel Era Post-Truth: Melawan Hoax dengan Fact Checking (Hartono, 2018) produksi berita palsu atau bohong tersebut tidak lepas dari fenomena posttruth, dimana kebenaran tidak lagi bersandar pada fakta melainkan pada perspektif subjektif (politik, agama, golongan, dst). Fenomena ini telah menempatkan masyarakat kepada situasi saling mencurigai. Khalayak tidak lagi dapat membedakan mana berita atau informasi valid, mana yang hoax. Dalam kasus yang dialami Ganis, ia menyadari bahwa anggota grup keluarganya tidak lagi bisa membedakan, apakah kabar yang pertama disampaikan yang benar, ataukah klarifikasi dari Ganis.

Hal serupa juga dialami oleh Meriana yang lebih memilih bersikap pasif mendiamkan kabar bohong yang beredar, "saya memilih diam untuk menghindari konflik dan perdebatan panjang."

Sementara Cindy memberikan contoh pada kasus-kasus perundungan di media sosial. Tanpa kejelasan latar belakang dan tanpa didukung informasi valid, seseorang bisa dihujani kritik bahkan sumpah serapah dari warganet. Untuk kejadian semacam ini, Cindy memilih bersikap pasif, 
"kalau ada orang yang minta viralkan sesuatu secara langsung kepada saya, bisa saya tolak, juga beritahu kalau itu salah. Tapi kalau kejadiannya pada orang lain, tidak ada kaitannya dengan saya, baiknya diam saja. Sudah pasti ada yang menyuarakan pendapatnya sesuai opini saya. Jadi saya tidak perlu."

Pertempuran antara nilai pribadi dan nilai sosial ini kerap kali berujung pada kekalahan nilai pribadi. "Terpaksa berkompromi" adalah jalan keluar yang dianggap terbaik. Seperti yang dikatakan Dini,

"diamkan dan senyum saja. Saya malas berdebat. Tentang agama, misal mengenai pandangan liberalisme, pandangan tentang LGBT, dan semacamnya. Dalam agama saya, hal tersebut sudah jelas-jelas dijelaskan sebagai perbuatan keji dan mungkar sehingga tidak ada kompromi untuk memakluminya, namun tetap berusaha untuk menghargai orang lain yang memiliki perspektif berbeda. [Saya rasa ini disebabkan] faktor enggan berkonflik dan cinta damai. Saya ingin menjaga hubungan baik dengan tidak membahas topik-topik yang sensitif."

Contoh lain dikemukakan Dini,

"Belakangan ini saya sedang berusaha untuk meminimalisir membagikan info seputar politik, terlebih jelang pilpres, karena saya memiliki beberapa teman yang saya tahu, memiliki pandangan dan pilihan politik yang berbeda dari saya. Selain ingin menjaga hubungan baik dengan mereka, saya pun merasa tidak ahli dalam politik. Misalnya, berita yang nyerempet ke capres cawapres, cukuplah dikomentari dalam hati saja. Saya diamkan saja karena tidak ada gunanya mendebat orang yang sudah punya pendirian sendiri, misalnya saja topik vaksin dan antivaksin, wah, membaca perdebatannya saja bikin lelah."
Jika seseorang individu melibatkan dirinya sendiri dalam situasi yang dinilainya sendiri, maka ia akan menjadikan dirinya sendiri sebagai patokan. Hanya hal-hal yang dekat dengan posisinya mau diterimanya. Makin terlibat individu itu, maka ambang penerimaannya makin tinggi dan makin sedikit hal-hal yang mau diterimanya. Asimilasi jadi makin kurang. Sebaliknya, ambang penolakan makin rendah, sehingga makin banyak hal-hal yang tidak bisa diterimanya. Hal ini makin terasa jika individu diperbolehkan menggunakan patokan-patokannya sendiri seberapa banyak pun dia anggap perlu.

Latitude of rejection yang mencakup gagasan yang ditolak karena tidak rasional juga muncul di dalam penelitian ini. Informan secara terang-terangan menolak menyetujui ide yang bertentangan apalagi menyebarluaskannya.

Mutadi sering mengurungkan niatnya untuk membagikan berita yang sebenarnya berasal dari fakta, namun berpotensi dipahami secara keliru,

“... khawatir jika informasi disalahartikan, semakin diketahui oleh umum justru semakin tidak baik kemudian menimbulkan excess negatif di masyarakat. Contohnya saja untuk berita berjudul 'Masjid Dirobohkan Akibat Proyek Tol' atau 'Delapan Vihara Dirusak Massa yang Marah."

Apa yang dikatakan Mutadi memang beralasan, karena judul berita semacam itu memang tergolong disinformasi ketika terjadi 
koneksi yang salah antara judul dan isi berita dan dapat mengakibatkan salah paham.

Dalam rangka menyetop persebaran kabar bohong, seseorang memang tidak cukup melaksanakan perilaku yang hanya diketahui oleh dirinya sendiri, melainkan juga perlu secara terbuka mengingatkan pihak-pihak yang aktif menyuarakan pendapat salah ini. Atiqa membuka kesempatan untuk tawar menawar,

"terlebih dahulu saya akan meminta dasar atau alasan menyampaikan hal tersebut kemudian menganalisis alasannya untuk dipertimbangkan dan dibandingkan dengan pendirian [saya sendiri]. Menurut saya tidak ada yang mutlak maka bisa saja informasi yang ia sampaikan memiliki nilai kebenaran. Maka perlu adanya diskusi dengan menunjukkan data-data dan fakta-fakta pendukung informasi yang sedang dibahas atau diinformasikan. Tidak serta merta langsung ditolak tergantung pada dasar menyampaikan informasinya seperti apa atau sejauh mana. Jika dasar atau alasan yang diberikan bisa masuk logika saya, akan saya pertimbangkan."

Posisi negoisasi juga menjadi pilihan Habib, ia beralasan bahwa diskusi untuk menyamakan persepsi. Yang salah harus diluruskan dan yang benar harus dilanjutkan. Ia menyebut informasi, konfirmasi, dan diskusi merupakan 3 hal penting. Tidak menolak dan menolak merupakan sebuah asumsi dari hasil diskusi.

Penolakan secara keras bukan berarti tidak menjadi pilihan. Efek kontras pun muncul saat pertimbangan sosial terjadi di dalam diri informan. Ganis mengakui bahwa argumentasinya pernah membuat pertemanannya dengan seseorang di media sosial berakhir.

"Banyak orang meremehkan mental health issues. Ada yang menyederhanakannya jadi depresi saja, ada pula yang malah menganggapnya sama dengan gila. Saya tidak bisa membiarkan orang dengan pemikiran seperti itu karena dia tidak mengalami apa yang saya alami."

Perubahan sikap seseorang terhadap objek sosial dan isu tertentu merupakan hasil proses penilaian yang terjadi dalam diri orang tersebut terhadap pokok persoalan yang dihadapi. Proses "menilai" isu atau objek sosial tersebut menurut berpatokan pada kerangka rujukan yang dimiliki seseorang. Kerangka rujukan inilah yang pada gilirannya menjadi "jangkar" untuk menentukan bagaimana seseorang memposisikan suatu pesan persuasif yang diterimanya. Tindakan memposisikan dan menyortir pesan yang dilakukan oleh alam bawah sadar terjadi sesaat setelah proses persepsi. Di sini setiap gagasan baru yang menerpa dinilai dengan cara membandingkannya dengan sudut pandang saat itu.

Dengan kata lain teori penilaian sosial menyatakan bahwa perubahan sikap seseorang terhadap objek sosial atau isu tertentu merupakan hasil proses pertimbangan yang terjadi dalam diri orang tersebut terhadap pokok persoalan yang dihadapi. Proses mempertimbangkan isu atau objek sosial tersebut berpatokan pada kerangka rujukan yang dimiliki seseorang. Kerangka inilah yang 
menjadi rujukan bagaimana seseorang memposisikan dan menyortir pesan yang diterima dan membandingkannya dengan sudut pandang yang rasional.

\section{PENUTUP}

Simpulan Implikasi literasi media dalam perubahan perilaku masyarakat kota Pontianak dalam menanggapi kabar bohong terlihat pada sikap individu yang mampu menahan diri untuk tidak dengan mudah membagikan suatu kabar kepada pihak lain walaupun kabar itu dianggap menarik. Sikap menahan diri ini muncul ketika mereka menandai ciri-ciri berita bohong pada suatu pesan.

Walaupun nilai-nilai mengenai anti misinformasi dan disinformasi telah dimiliki para individu, ternyata tidak selalu merespon stimulus berupa kabar bohong dengan cara yang sama. Hal ini bukan disebabkan oleh manipulasi yang dibuat kabar bohong mampu mengelabui mereka, melainkan karena kabar tersebut juga disebarkan oleh pihak-pihak lain yang belum memiliki nilai-nilai serupa, yang tidak mungkin bisa ditahan lajunya oleh para individual yang paham literasi media.

Mengacu pada teori penilaian sosial, kesesuaian rujukan nilai yang dimiliki individu dengan ide yang ditawarkan oleh kabar bohong, khususnya berkaitan dengan adanya persuasi karena kesamaan kepentingan dan minat tidak selalu berujung pada penerimaan ide. Individu melakukan penyaringan pesan dan hanya mau menyebarluaskan ide yang memang telah diyakini akurat dan tidak merugikan pihak lain. Hal ini menempatkan individu di dalam wilayah garis lintang nonkomitmen.

Di lain pihak, ketidaksesuaian rujukan nilai yang dimiliki individu dengan ide yang ditawarkan oleh kabar bohong, baik diperkuat oleh keterlibatan ego maupun tidak, bermuara pada beberapa jenis perilaku:

1. Berdiam diri, tidak secara aktif menyuarakan ketidaksetujuan, namun memilih diam demi menjaga hubungan sosial, yang membawa individu justru berada di dalam wilayah garis lintang penerimaan.

2. Kompromi, melakukan diskusi untuk mencapai kesepakatan mengenai fakta dan data yang akurat, yang juga membawa individu berada di dalam wilayah garis lintang penerimaan.

3. Penolakan aktif, mengajukan argumentasi dengan tujuan agar ide individu balik diterima oleh lawan, yang membawa individu berada di dalam wilayah garis lintang penolakan.

Saran Literasi media merupakan keterampilan yang wajib dimiliki oleh semua orang di era berbagi informasi saat ini. Sebagian orang sudah menyadarinya dan berupaya mempelajari keterampilan ini secara mandiri dengan cara banyak membaca. Pelatihan-pelatihan keterampilan mengenainya 
harus terus digiatkan terutama melalui sekolahsekolah dan kampus-kampus.

Para pegiat literasi media juga perlu mendorong para partisipan kegiatan literasi media tidak berhenti hanya pada secara pasif menahan diri untuk tidak menyebarkan berita bohong saja, justru secara aktif menyebarluaskan kesadaran mereka mengenai literasi media ini.

\section{DAFTAR PUSTAKA}

APJII. (2017). Infografis Survei Penetrasi dan Perilaku Pengguna Internet Indonesia. Diakses dari http://apjii.id pada $10 \mathrm{Mei}$ 2018.

bbcindonesia.com. (2018). Ungkapan 'hoax membangun' ketua Badan Siber Djoko Setiadi yang 'hanya pancingan'. Diakses darihttps://www.bbc.com/indonesia/trens osial-42563616 pada 1 September 2018.

fisip.untan.ac.id. (2017). Literasi Media Bersama HIMAKOM. Diakses dari http://fisip.untan.ac.id/index.php/2017/1 0/05/literasi-media-bersama-himakom/

Griffin, Em. (2002). A First Look at Communication Theory. 5th ed. New York: McGraw-Hill.

Hartono, Dudi. (2018). Era Post-Truth: Melawan Hoax dengan Fact Checking. Prosiding Seminar Nasional Prodi Ilmu Pemerintahan. Diakses dari http://repository.fisipuntirta.ac.id/952/1/Naskah\%205.pdf pada 1 September 2018.

Ireton, Cherilyn and Julie Posetti (Ed.). (2018). Journalism, 'Fake News' \& Disinformation: Handbook for
Journalism Education and Training, France: UNESCO.

Kriyantono, Rachmat. (2007). Teknik Praktis Riset Komunikasi. Jakarta: Kencana Perdana Media Grup.

Mastel. (2017). Hasil Survey Mastel tentang Wabah Hoax Nasional. Diakses dari http://mastel.id pada 10 Mei 2018.

Miles, Matthew B. \& Huberman, A Michael. (1992). Analisis Data Kualitatif. Terjemahan Tjetjep Rohendi Rohidi. Jakarta : UI Press

mimbaruntan.com. (2017). Ketua AJI Pontianak Sampaikan Tips Lawan Hoaks. Diakses dari http://mimbaruntan.com/ketua-ajipontianak-sampaikan-tips-lawan-hoax/

Molteni, Megan. 2018. When WhatsApp's Fake News Problem Threatens Public Health. Diaksesdarihttps://www.wired.com/story /when-whatsapps-fake-news-problemthreatens-public-health/ pada 10 Mei 2018.

Oxtora, Rendra (2017). Workshop anti hoax di Pontianak. Diakses dari https://kalbar.antaranews.com/berita/360 924/workshop-anti-hoax-di-pontianak

Pawito. (2007). Penelitian Komunikasi Kualitatif. Yogyakarta: LkiS.

pontianakpost.co.id. (2017). Galakkan Literasi Media, Sejumlah Organisasi Gelar Aksi Solidaritas. Diakses dari https://www.pontianakpost.co.id/galakka n-literasi-media-sejumlah-organisasigelar-aksi-solidaritas

Remotivi. (2016). Savic Ali: Media-media Garis Keras Punya Semangat Mengimpor Konflik http://www.remotivi.or.id/wawancara/27 4/Savic-Ali:-Media-Media-Garis-Keras- 
Punya-Semangat-Mengimpor-Konflik pada Diakses pada tanggal 1 April 2018.

safenetvoice.org. (2018). Laporan Kegiatan Bulan \#AmanInternetan Pontianak: Menjegal Mata-Mata di Kantong Kita. Diaksesdarihttp://id.safenetvoice.org/201 8/03/laporan-bulan-amaninternetanpontianak-menjegal-mata-mata-dikantong-kita/

sinarharapan.net. (2017). Provinsi Kalbar Gelar Kampanye Lawan Hoax. Diakses darihttp://sinarharapan.net/2017/03/provi nsi-kalbar-gelar-kampanye-lawan-beritahoax/

Sholih, Mufti. (2018). Memangnya Ada Hoax yang Positif dan Membangun? Diakses dari https://tirto.id/memangnya-adahoax-yang-positif-dan-membanguncCKb pada 1 September 2018.

Sudarso. (2006). Prosedur Penelitian. Dalam Suyanto \& Sutinah (ed). Metode Penelitian Sosial. Hal 53-56. Jakarta: Kencana Media Prenada Group.

Taba, Abdul Salam. (2018). Hoax Membangun? Diakses dari https://news.detik.com/kolom/d3804390/hoax-membangun pada $10 \mathrm{Mei}$ 2018.

teraju.id. (2017). 108 Peserta Pontianak Ikuti Workshop Literasi Media Melawan Radikalisme dan Terorisme. Diakses dari http://teraju.id/berita/108-pesertapontianak-ikuti-workshop-literasimedia-melawan-radikalisme-danterorisme-4861/ turnbackhoax.id. (2018). AJI Pontianak Gelar Pelatihan Anti Hoaks di RRI. Diakses darihttps://turnbackhoax.id/2018/04/16/b erita-aji-pontianak-gelar-pelatihan-antihoaks-di-rri/

Sinaga, Edo. (2017). Isu Hoax Penculikan Anak di Kalbar Makan Korban, Seorang Kakek Tewas Dihakimi Massa. Diakses dari http://kbr.id/nasional/03-

2017/isu_hoax_penculikan_anak_di_kal bar_makan_korban_sseorang_kakek_te was_dihakimi_massa/89442.html

Vosoughi, Soroush, Deb Roy, and Sinan Aral. (2018). The spread of true and false news online. Science 09 Mar 2018:Vol. 359, Issue 6380, pp. 1146-1151. DOI: 10.1126/science.aap9559.

We Are Social. (2018). Digital in 2018 in Southeast Asia Part 2 - South-East. Diakses dari https://www.slideshare.net/wearesocial/d igital-in-2018-in-southeast-asia-part-2southeast-86866464 pada 10 Mei 2018.

Widhyatmoko, Danu. (2011). Ponsel Lebih Dari Sekedar Alat Komunikasi. JurnalHumaniora, 2 (1), April, 360-367.

Yusuf, Oik. (2017). Perlawanan "Netizen" Lahirkan Masyarakat Anti-"hoax". Diaksesdarihttps://tekno.kompas.com/re ad/2017/01/08/10495047/perlawanan.net izen.lahirkan.masyarakat.anti-.hoax. pada 10 Mei 2018. 